\title{
FUTURE PERSPECTIVES OF DPT STUDENTS IN PAKISTAN
}

\author{
Iqra Yaseen ${ }^{1}$, Anam Aftab², Rimsha Malik ${ }^{3}$, Suman Sheraz \\ ${ }^{1}$ Department of Physiotherapy, University of Lahore, Islamabad Campus - Pakistan \\ ${ }^{2}$ Department of Rehabilitation, Riphah International University, Islamabad - Pakistan \\ ${ }^{3}$ Department of Physiotherapy, Federal Institute of Health Sciences, Muzaffarabad General Hospital, \\ Muzaffarabad- Pakistan \\ ${ }^{4}$ Department of Rehabilitation, Riphah International University, Islamabad - Pakistan
}

\begin{abstract}
Objectives: To explore the current trends, challenges and future perspectives of physiotherapy in terms of social awareness, job availability and career orientation in Pakistan

Material and Methods: A cross-sectional study was conducted on 200 physiotherapy students at Rawalpindi Medical University Rawalpindi, Benazir Bhutto Hospital Rawalpindi and Maroof International Hospital Islamabad for 6 months. Non-probability convenience sampling was used. Fresh graduates of physiotherapy and postgraduate students studying physiotherapy were included in this study. All the students having experience of more than 3 years and students other than physiotherapy profession were excluded. Questionnaire was designed with responses according to Likert scale from strongly agree to strongly disagree. Statistical analysis was done using SPSS 21.

Results: The results showed agreement of $49 \%$ participants with the fact that social unawareness of physiotherapy field is one of the major factors affecting its scope. Whereas, 33\% participants strongly agreed that poor referral by physicians influences this awareness among people.

Conclusion: Physiotherapy in Pakistan is at its developing phase and needs a lot of improvement. There are limited job opportunities and limited education facilities in institutes, leading to increased stress and career insecurity in physiotherapy students.
\end{abstract}

Key words: Physiotherapy, future perspectives .

This article may be cited as: Yaseen I, Aftab A, Malik R, Sheraz S. Future perspectives of DPT students in Pakistan. J Med Sci 2021 January;29(1):34-37

\section{INTRODUCTION}

Physiotherapy, a branch of health sciences, is a profession focused on assessment, diagnosis and function of human movement and functions maximizing its potential ${ }^{1}$. Physiotherapy uses physical techniques to promote, maintain and restore physical, psychological and social well-being, taking into account variations in health status $^{2}$.

According to Al-Eisa et al., in the past few years, physiotherapy has been known for the best way of treatment to eliminate dependency and disability, but the field is yet to be recognized in an effective manner ${ }^{3}$.

\section{Correspondence}

\section{Dr. Rimsha Malik}

Department of Physiotherapy, Federal Institute of Health

Sciences, Muzaffarabad General Hospital,

Muzaffarabad - Pakistan

Email: misha.malik1231996@gmail.com

Cell: $+92-335-54540327$

Date received: $27-10-2020$

Date revised: $\quad 02-01-2021$

Date accepted: $02-02-2021$
Presently, there is no regulatory authority in the country to regulate and standardize this profession. Although there is much work done in private sector regarding role and importance of physiotherapy in today's challenging health care environment but in public sector, there is minimal facilitation for professional therapists. The graduates from Pakistan are serving other countries with satisfactory performance but physiotherapists in Pakistan are victims of low wages and lack of jobs specifically on clinical side ${ }^{4}$. Keeping in mind the importance and need of physiotherapy, students decide to adopt this profession but unfortunately, the current situation in the country forces fresh graduates to go abroad for better future.

According to the estimates of health sector and future tendencies of public medicine, the degree in physiotherapy is in the race for a greater future internationally ${ }^{5}$. Though there is an intensive need of specialized people who should provide treatment for physical rehabilitation of human beings, but lack of interest in students due to deficient recognition and job unavailability leads to avoidance of choosing physiotherapy as a profession. 
Accordingly, highlighting the challenges faced by fresh graduates, very few researches have been conducted regarding job orientation and social recognition of the field. In 2014, Dahl-Michelsen stated that in developing countries, the future of physiotherapy field is continuously evolving ${ }^{6}$. However, there are few factors which need greater attention of both physiotherapy associations and government initiatives to introduce the field appropriately. Researchers have further stated that lack of professional ethics, insufficient training for graduates, lack of awareness in public and absence in development of rehabilitation measures greatly influence rehabilitation process $^{7}$

Along with other major challenges, inadequate education standards in third world countries are one of the biggest challenges for physiotherapy students. Most of the universities or colleges in developing countries are offering physiotherapy programs without any practical and scientific knowledge, which not only develops deficiency of knowledge among the students but also develops hesitation in healthcare society to recognize them as professional doctors of specific profession ${ }^{8}$.

There is a lack of research particular to future perspectives and challenges of physiotherapy faced by students and fresh graduates in Pakistan. Fewer studies have been conducted on social awareness of physiotherapy. In this context, this study was aimed to explore the current trends, challenges and future perspectives of physiotherapy in terms of social awareness, job availability and career orientation.

\section{MATERIAL AND METHODS}

A cross-sectional study was conducted at Rawalpindi Medical University Rawalpindi, Benazir Bhutto Hospital Rawalpindi and Maroof International Hospital Islamabad for 6 months. Non-probability convenience sampling was used and a sample size of 200 was selected as calculated by the WHO calculator. Fresh graduates of physiotherapy and postgraduate students studying physiotherapy were included in this study. All the students having experience of more than 3 years and students other than physiotherapy profession were excluded. The survey was conducted after taking participants' consent. Ethical considerations were kept in mind while designing the questionnaire and conducting the survey. Questionnaires among 200 students were distributed to examine the current trends, future perspectives and awareness about physiotherapy. Questionnaire was designed with Likert scale responses (from strongly agree to strongly disagree). Statistical analysis was done using SPSS 21 to analyse findings and interpret the results.

\section{RESULTS}

Among these 200 participants in the study, 95 $(47 \%)$ were male and 105 (53\%) were female. One-hun- dred and eighty seven of these participants had working experience of less than 1 year in physiotherapy field, whereas 13 participants had up to 3 years of experience.

\section{DISCUSSION}

Physiotherapy is an emerging field and has been shown to have a positive effect on outcome of physically disabled patients. Physiotherapy is regarded as lucrative white collar profession in western countries. Physiotherapy is among the hall marks of rehabilitation but students have to face a lot of challenges here in Pakistan ${ }^{9}$. Graduates still have fear about their future even after studying for five years because they are hired at low wages which is not sufficient enough. This behaviour is increasing further frustrations among them. Students are being graduated and in the meantime not finding relevant jobs, that leads to stress and career insecurity. In such cases, students get depressed. In 2011, a study conducted by Fisher reported a lack of job structure and well trained teachers ${ }^{10}$. Similar is the case in Pakistan where $87 \%$ participants agreed that due to lack of professional mentoring, students have problems performing up to their limits. Unawareness and mentoring is interrelated; people are unaware thus they are not interested towards getting training and guidance in this field. They are unaware of its role and importance and are not guided by professionals appropriately for choosing the right path and building their career in an effective manner. Regarding these challenges faced by graduates, Higgs and his colleagues indicated in their research that physiotherapy field has always been full of challenges for the students and professionals whether getting job or moving ahead in the field ${ }^{11}$. A study conducted in Qatar in 2017 , indicated that unfavourable contracts and low pays are two of the major challenges faced by physiotherapists in Qatar ${ }^{12}$. This is similar to the results of current study as $68 \%$ participants agreed that limited numbers of jobs are there with low pay rates; however, no such questions were asked regarding employment contracts. Lack of clinical facility leads to job unavailability and disappointment among the students. In 2014, a national study conducted by Babur et al., found that although few universities of $\mathrm{Pa}-$ kistan have introduced this field during recent years and incorporated research at undergraduate level but social awareness and job opportunities have not been up to the mark as compared to other countries ${ }^{9}$. Similar result has been shown by this study as $70 \%$ participants agreed that though, physiotherapy education started more than a decade before, but the field still needs recognition. Again, the main point is awareness and recognition whether it is about students or public; if the students are well aware of its importance, they can convey it to the people in the field. Similarly, if people are well aware of it, they can consider it a way of treatment while having related health issues. So, there is a connection between awareness and recognition among students and public that should be considered by the government. It was mentioned in the 8th world 
Future Perspectives Of Dit Students In Pakistan.

Table 1: Trends among Physiotherapists

\begin{tabular}{|c|c|c|c|c|c|}
\hline No & Questions & Strongly Agreed & Partially Agreed & Neutral & Disagreed \\
\hline 1 & $\begin{array}{c}\text { Social unawareness of your field is one of the major fac- } \\
\text { tors affecting the scope of field }\end{array}$ & $49 \%$ & $27 \%$ & 21 & $3 \%$ \\
\hline 2 & $\begin{array}{l}\text { Poor referral by physicians also influences people aware- } \\
\text { ness related to physiotherapy }\end{array}$ & $33 \%$ & $38 \%$ & $17 \%$ & $12 \%$ \\
\hline 3 & $\begin{array}{l}\text { Government or health administration is taking positive } \\
\text { steps to enhance awareness among people }\end{array}$ & $17 \%$ & $21 \%$ & $17 \%$ & $45 \%$ \\
\hline 4 & $\begin{array}{l}\text { Due to long recovery time, people lose interest in thera- } \\
\text { peutic treatments }\end{array}$ & $28 \%$ & $37 \%$ & $11 \%$ & $24 \%$ \\
\hline 5 & $\begin{array}{l}\text { Though, physiotherapy education started more than a } \\
\text { decade before, but the field still needs recognition }\end{array}$ & $22 \%$ & $48 \%$ & $12 \%$ & $18 \%$ \\
\hline 6 & $\begin{array}{c}\text { Overcrowding of private institutes in physiotherapy field } \\
\text { can develop the issue of job unavailability due to limited } \\
\text { number of vacancies offered by government and private } \\
\text { health institutes }\end{array}$ & $28 \%$ & $23 \%$ & $15 \%$ & $34 \%$ \\
\hline 7 & $\begin{array}{c}\text { The limited number of jobs and access to clinical health } \\
\text { settings enhance the possibility of social and financial } \\
\text { stress to meet career objectives }\end{array}$ & $24 \%$ & $44 \%$ & $16 \%$ & $16 \%$ \\
\hline 8 & $\begin{array}{l}\text { Government and other stakeholders are taking interests to } \\
\text { enhance the recognition of physiotherapy field }\end{array}$ & $16 \%$ & $23 \%$ & $34 \%$ & $27 \%$ \\
\hline 9 & $\begin{array}{l}\text { Due to social unawareness and health care lack of inter- } \\
\text { ests, the graduates confront difficulties in finding job and } \\
\text { private practice }\end{array}$ & $21 \%$ & $39 \%$ & $18 \%$ & $22 \%$ \\
\hline 10 & $\begin{array}{l}\text { Limited access to knowledge acquisition facilities such as } \\
\text { clinical facility raises concerns of knowledge deficiency in } \\
\text { graduates }\end{array}$ & $16 \%$ & $45 \%$ & $14 \%$ & $25 \%$ \\
\hline 11 & $\begin{array}{l}\text { In order to enhance practical knowledge students must } \\
\text { have clinical facility where they can implement the theoreti- } \\
\text { cal knowledge and learn by exposure }\end{array}$ & $50 \%$ & $33 \%$ & $4 \%$ & $13 \%$ \\
\hline 12 & $\begin{array}{l}\text { Due to lack of professional mentoring, students have prob- } \\
\text { lems performing up to their aptitude }\end{array}$ & $38 \%$ & $49 \%$ & $3 \%$ & $10 \%$ \\
\hline 13 & $\begin{array}{l}\text { Private institutes are offering education at low eligibility } \\
\text { standards which ultimately results in production of incom- } \\
\text { petent resource }\end{array}$ & $14 \%$ & $49 \%$ & $11 \%$ & $26 \%$ \\
\hline 14 & $\begin{array}{l}\text { Due to high fee structure of private institutes, consider- } \\
\text { able amount of investment for knowledge acquisition is } \\
\text { required }\end{array}$ & $28 \%$ & $43 \%$ & $17 \%$ & $12 \%$ \\
\hline 15 & $\begin{array}{l}\text { Recent awareness activities in physiotherapy field are } \\
\text { promoting the scope and future perspective }\end{array}$ & $17 \%$ & $39 \%$ & $22 \%$ & $22 \%$ \\
\hline
\end{tabular}

physiotherapists summit conducted in Japan (2018) that physiotherapy across the globe has gone through positive changes with enhanced career opportunities for fresh graduates. Whereas the situation in Pakistan is different as per current findings, $60 \%$ participants agreed that due to social unawareness and lack of interests, the graduates confront difficulties in finding job and private practice. This situation is worsening progressively and government must take measures to save this profession. Institutions offering this degree do not meet the requirements except a few ones. Government should ban such type of institutions which are wasting time and money. This is what the current study also refers to; as $63 \%$ participants agreed that private institutes offering education at low eligibility standards are ultimately resulting in production of incompetent physiotherapists.
According to the findings, people are less aware of physiotherapy, its role and importance and only $38 \%$ participants agreed to this fact that government is taking initiatives to improve awareness among people. Likewise, a study conducted to find awareness among high school students concluded that not much awareness regarding physiotherapy career is there ${ }^{13}$. In addition, it was found that measures are required to improve awareness regarding physiotherapy ${ }^{14}$.

DPT is an honoured degree worldwide. It is one of those degrees that will be in demand in coming years. To uplift this field in Pakistan and to open new vistas for national and international cooperation, government and owners of physiotherapy societies should engage themselves whole-heartedly. In this regard, only $39 \%$ participants in this study agreed that the government and other 
stakeholders are taking interests to enhance the recognition of physiotherapy field.

Although Pakistani government is taking initiative to some extent to promote the scope of physiotherapy, however social unawareness, job unavailability, lack of clinical facilities are yet to be considered. Physical therapy practice has moved to direct access instead of referral of the patients both internationally as well as nationally. This puts a great responsibility on the shoulders of the physical therapists to be well equipped with knowledge and skills to serve the humanity.

\section{CONCLUSION}

Physiotherapy in Pakistan is at its developing phase and needs a lot of improvement. There are limited job opportunities and limited education facilities in institutes. Social unawareness and lesser opportunities thus result in increased stress and career insecurity in physiotherapy students and graduates. At the same time, overcrowding of private institutes and lack of clinical facilities are required. However, mass advertisements of the potential benefits of physiotherapy can lead to increased number of job opportunities and better growth of the profession.

\section{REFERENCES}

1. Harvey LA, Glinsky JV, Bowden JL. The effectiveness of 22 commonly administered physiotherapy interventions for people with spinal cord injury: a systematic review. Spinal cord. 1 Nov 2016;54(11):914-23.

2. Dissanayaka TD, Banneheka S. Awareness in physiotherapy among high school students. International Journal of Scientific and Research Publications. 2014;4(7):1-5.

3. Al-Eisa ES, Al-Hoqail H, Al-Rushud AS, Al-Harthi A, AlMass B, Al-Harbi BM, Al-Azzaz S, Alghadir AH, lqbal ZA. Awareness, perceptions and beliefs about physiotherapy held by physicians working in Saudi Arabia: a cross-sectional study. Journal of physical therapy science. 2016;28(12):3435-9.

4. Haider A. Physiotherapy: a neglected field. DAWN.COM. 2017 September 19, available at: https://www.dawn. com/news/668183

5. Olsen NR, Bradley P, Lomborg K, Nortvedt MW. Evidence based practice in clinical physiotherapy education: a qualitative interpretive description. BMC medical education. 2013 Apr 11;13(1):52.

6. Dahl-Michelsen T. Sportiness and masculinities among female and male physiotherapy students. Physiotherapy theory and practice. $2014 \mathrm{Jul}$ 1;30(5):329-37.
7. Smeddinck JD, Herrlich M, Malaka R. Exergames for physiotherapy and rehabilitation: a medium-term situated study of motivational aspects and impact on functional reach. InProceedings of the 33rd Annual ACM Conference on Human Factors in Computing Systems 2015 Apr 18 (pp. 4143-4146).

8. Leirós-Rodríguez R, Souto-Gestal AJ, García-Soidán $\mathrm{JL}$. Post-graduate education requirements for access to jobs in physical therapy. Educación Médica. 2018 Oct 1;19:79-84.

9. Babur MN, Siddique FR, Awan WA. Future of physical therapy in Pakistan-Satisfaction amongst Pakistani physical therapists about their profession. Isra Medical Journal. 2014;6(1):25-7.

10. Fisher C. 5 Physical therapy career challenges. 2011, available at: http://www.businessinsider.com/5-physical-therapy-career-challenges-2011-12

11. Higgs, Kathryn Refshauge, Elizabeth Ellis J. Portrait of the physiotherapy profession. Journal of interprofessional care. 2001 Jan 1;15(1):79-89.

12. Alenazi R. Physiotherapists challenges in Qatar and their effect on performance and retention. 2017.

13. Dissanayaka, T. D., \&Banneheka, S. (2014). Awareness in physiotherapy among high school students. International Journal of Scientific and Research Publications, 4(7), 1-5.

14. Doshi, D., Jiandhani, M., Gadgil, R., \& Shetty, N. (2017). Physiotherapy awareness in Medical and non Medical Population: A social Media Survey. International Journal of Physiotherapy and Research, Int J Physiother, Vol 5(2):1971-75.

CONFLICT OF INTEREST: Authors declare no conflict of interest

GRANT SUPPORT AND FINANCIAL DISCLOSURE: NIL

\section{AUTHOR'S CONTRIBUTION}

Following authors have made substantial contributions to the manuscript as under

Yaseen I: $\quad$ Main Idea, Data Collection and analysis.

Aftab A: Data analysis, Manuscript writeup.

Malik R: $\quad$ Manuscript writeup.

Sheraz S: Proof reading, bibliography.

Authors agree to be accountable for all aspects of the work in ensuring that questions related to the accuracy or integrity of any part of the work are appropriately investigated and resolved. 